\title{
Salvage Stereotactic Body Radiosurgery in the Management of Recurrent Gynecological Cancer
}

\author{
Gozde YAZICI ${ }^{1}$, Mustafa CENGIZ1 ${ }^{1}$, Gokhan OZYIGIT' ${ }^{1}$, Guler YAVAS ${ }^{2}$, Ali AYHAN ${ }^{3}$, \\ Murat GURKAYNAK ${ }^{1}$, Ferah YILDIZ ${ }^{1}$ \\ ${ }^{1}$ Hacettepe University, Faculty of Medicine, Department of Radiation Oncology, Ankara \\ ${ }^{2}$ Selcuk University, Faculty of Medicine, Department of Radiation Oncology, Konya \\ ${ }^{3}$ Baskent University, Faculty of Medicine, Department of Obstetrics and Gynecology, Ankara, TURKEY
}

\begin{abstract}
Local tumor persistence in the pelvis is the major cause of death in patients with recurrent gynecological cancer. Pelvic exenteration has been the only treatment option providing a chance for cure in selected patients. The aim of this study is to analyze the efficacy of stereotactic body radiosurgery (SBRS) in patients with recurrent gynecological cancer. Sixteen patients treated with SBRS were analyzed retrospectively. The majority of the patients had cervical cancer. Eleven patients had a history of prior radiotherapy either as postoperative adjuvant external beam radiotherapy (EBRT) with a median dose of 50.4 Gy (range 45-60 Gy) or definitive chemoradiotherapy as EBRT and high dose rate brachytherapy with a dose of 85-90 Gy low dose rate equivalent to point A. The prescribed dose of SBRS was 15-40 Gy (mean 26.6 Gy) in 3-5 fractions. Five patients with no prior radiotherapy received additional EBRT before SBRS. The median follow-up in all patients is 12 months (range 3-36 months). Six patients (37.5\%) showed complete radiological and functional response to salvage SBRS. Six patients (37.5\%) showed partial response and 2 (12.5\%) showed stable disease. One and 2 year overall survival rates are $60.3 \%$ and $40.2 \%$ respectively. Progression free survival is $59 \%$. All patients with complete response after SBRS are alive with no evidence of disease with a median follow up time of 20 months. SBRS is a promising treatment modality with high local control and reasonable complication rates in selected patients with recurrent gynecological cancer.
\end{abstract}

Keywords: Cyberknife, Radiotherapy, Recurrent gynecological cancer, Salvage, Stereotactic radiosurgery

\section{ÖZET}

\section{Rekürren Jinekolojik Kanser Tedavisinde Kurtarma Amaçlı Stereotaktik Vücut Radyocerrahisi}

Lokal- bölgesel yineleme gözlenen jinekolojik kanserli hastalarda ölüm nedeni çoğunlukla bölgesel hastalıktır. Seçilmiş grup hastada pelvik ekzenterasyon kür için tek seçenek olmuştur. Bu çalışmanın amacı stereotaktik vücut radyocerrahisinin (SVRC) reküren jinekolojik kanserli hastalarda etkinliğini araştırmaktır. SVRC ile tedavi edilen 16 hasta retrospektif olarak değerlendirilmiştir. Hastaların büyük çoğunluğunun tanısı serviks kanseridir. On bir hastanın ilk tedavisinde postoperatif ya da küratif radyoterapi uygulanmışır. SVRC ile reçete edilen doz 15- 45 Gy' dir (ortalama 26.6 Gy) ve 3-5 fraksiyonda uygulanmıștır. Daha önce radyoterapi uygulanmayan hastalara eksternal tedavi SVRC öncesinde uygulanmıştır. Ortanca takip 12 aydır (3- 36 ay). Altı hastada (\%37.5) radyolojik olarak tam cevap elde edilmiştir. Altı hastada parsiyel cevap (\%37.5) ve iki hastada stabil hastalık (\%12.5) gözlenmiştir. Bir ve 2 ylllık genel sağ kalım oranları sırası ile \% 60.3 ve \% 40.2' dir. Progresyonsuz sağ kalım \% 59' dur. Tam cevap alınan hastaların tamamı ortanca 20 ayllk takipte hastalıksız hayattadır. SVRC yüksek lokal kontrol oranları ve nispeten düşük komplikasyon yüzdesi ile reküren jinekolojik kanserli hastalarda seçilmiş bir grupta iyi bir tedavi seçeneğidir.

Anahtar Kelimeler: Cyberknife, Radyoterapi, Rekuren jinekolojik kanser, Kurtarma tedavisi, Stereotaktik radyocerrahi 


\section{INTRODUCTON}

Advanced stage gynecological tumors and their corresponding recurrences share unfavorable prognosis. The recurrence rate of cervical cancer is in the range of $10-20 \%$ in early stages and $50-70 \%$ in locally advanced disease. ${ }^{1-3}$ Patients with recurrent or persistent disease have very poor prognosis with reported one year survival rate of $15-20 \%$, local tumor persistence in the pelvis is the major course of death. ${ }^{3.4}$ Treatment options depend on the previous treatment, site and extent of the disease, and patient's general condition. Pelvic exenteration, first introduced by Alexander Brunschwig in 1948 has been proven to be the only treatment option providing a chance for cure especially in patients who received prior radiotherapy. ${ }^{5}$ Since the main goal of surgery is complete removal of the tumor with free margins, the indication for pelvic exenteration is restricted only to central pelvic disease. ${ }^{6}$

Stereotactic body radiosurgery (SBRS) is a novel treatment modality which allows high radiation dose delivery in a co or non-coplanar fashion with high precision in a single or few fractions utilizing a linear accelerator mounted on a robotic arm. In recent years though having limited number of patients and follow-up time, encouraging results have been published with SBRS in recurrent or metastatic tumors located in abdomino-pelvic and thoracic sites. ${ }^{7-10}$ In this study we aimed to analyze the clinical outcome and the toxicity with salvage SBRS in patients who developed recurrence after primary surgery and/or radiotherapy or radiochemotherapy.

\section{PATIENTS AND METHODS}

Between October 2007 and July 2010, 16 patients with recurrent gynecological cancer were treated with SBRS in Hacettepe University Faculty of Medicine, Department of Radiation Oncology. Patient characteristics are listed in Table 1. The median age at the time of SBRS was 61 years (ranged 43-77 years). The majority of the patients had cervical cancer. Eleven out of 16 patients in our series had a history of radiotherapy either as postoperative adjuvant external beam radiotherapy (EBRT) or definitive chemoradiotherapy (CRT). Prior postoperative EBRT dose was in the range of 45-60 Gy with a median dose of $50.4 \mathrm{~Gy}$. Three patients with diagnosis of locally advanced cervical cancer had been

\begin{tabular}{|ll|}
\hline Table 1. Patient characteristics \\
\hline $\begin{array}{ll}\text { Number of patients } \\
\text { Age }\end{array}$ & 16 \\
Primary tumor & $43-77$ (mean 61years) \\
Cervical Cancer & $11(69 \%)$ \\
Endometrial cancer & $4(25 \%)$ \\
Ovarian cancer & $1(6 \%)$ \\
Primary Treatment & $4(25 \%)$ \\
S & $3(19 \%)$ \\
S+EBRT & $5(31 \%)$ \\
S+CCRT & $3(19 \%)$ \\
CCRT+BRT & $1(6 \%)$ \\
S+CT & \\
Site of recurrence & $9(56 \%)$ \\
Central pelvic & $4(25 \%)$ \\
Parailiac & $2(13 \%)$ \\
Pelvic side wall & $1(6 \%)$ \\
Low paraaortic & \\
\hline S: Surgery; EBRT: External beam radiotherapy; \\
CCRT: Concomitant chemoradiotherapy; BRT: Brachytherapy; \\
CT: Chemotherapy
\end{tabular}

treated with a course of EBRT and concomittant cisplatin based chemotherapy in addition to high dose rate brachytherapy (BRT). The prescribed dose to point A with BRT and EBRT was 85-90 Gy low dose rate equivalent.

The median time to recurrence or progression of the disease after primary treatment was 20 months with a range of 6-63 months. Site of recurrence was central pelvic in 9 patients and parailiac $(n=4)$, pelvic side wall $(n=2)$ and low paraaortic $(n=1)$ in 7 patients. Four patients had undergone one or two salvage surgeries and 4 patients were treated with chemotherapy before SBRS. Four patients with no previous radiotherapy history were given a course of external beam pelvic radiotherapy with concomitant cisplatin based chemotherapy and one patient with a history of previous pelvic radiotherapy who developed paraaortic recurrence received paraaortic irradiation before SBRS. The prescribed dose of external radiotherapy in these patients was in the 


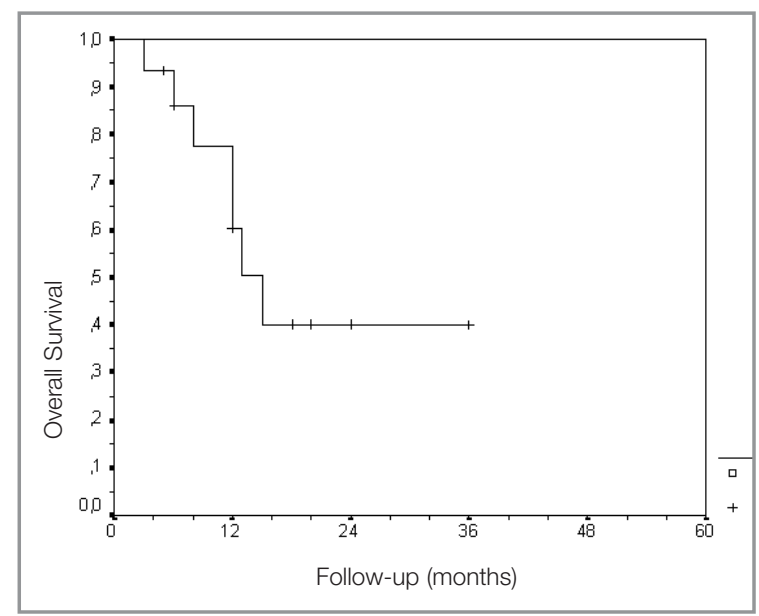

Figure 1. Overall survival after stereotactic body radiosurgery

range of 45-50.4 Gy (median 50.4 Gy). The volume of the recurrent tumor at the time of SBRS was in the range of 25.7-310 cc with a mean volume of $111.1 \mathrm{cc}$. There were no other local or distant metastases.

The prescribed dose of SBRS was 15-40 Gy (mean $26.6 \mathrm{~Gy}$ ) in 3-5 fractions. The mean isodose level for dose prescription was 76\% (ranged 60-76). The maximum dose was 18.5-58.1 Gy (mean dose 35 Gy). The mean conformality index and homogeneity indices were 1.64 (range 1.12-2.67, std 0.33 ) and 1.32 (range 1.2-1.67, std 0.12) respectively. The prescribed dose in 5 patients who received a course of external radiotherapy was in the range of $15-28$ Gy in 3-5 fractions.

Statistics: Overall survival, survival after reirradiation, progression-free survival, and survival curves were computed using the Kaplan-Meier method and compared using the Cox-Mantel log-rank test. All statistical analyses were performed using SPSS v.15.0 for Windows.

\section{RESULTS}

After SBRS all patients were routinely followed up at 2, 4, and 6 months and quarterly thereafter. At each visit a thorough general physical examination in addition to gynecological examination was performed. Routine magnetic resonance imagings (MRI) at 2 months and PET scan at 4 months after SBRS were also performed in all patients. Additi-

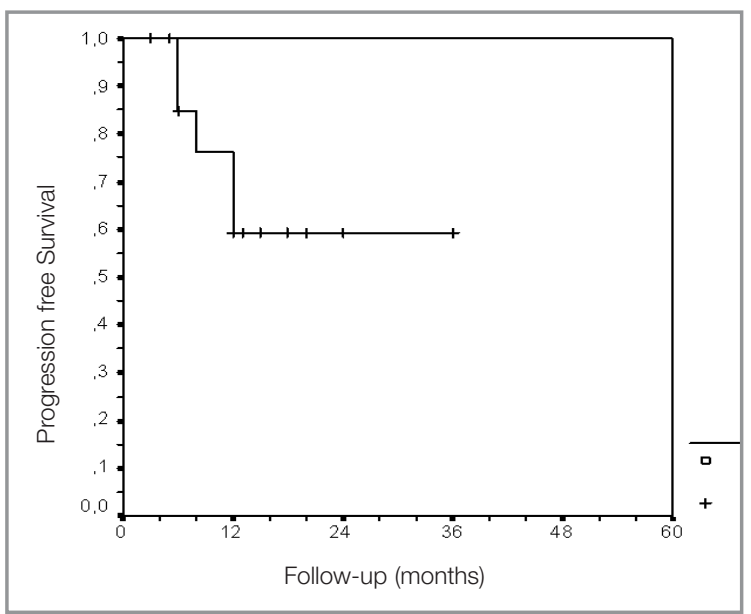

Figure 2. Progression free survival after stereotactic body radiosurgery

onal MRI sections were taken twice annually in patients who showed complete radiological response. Routine blood tests and chest radiograms were taken in each visit.

The follow-up time after salvage SBRS is 12 months (range 3-36 months). One and 2 year overall survival after SBRS is $60.3 \%$ and $40.2 \%$ respectively (Figure 1). The corresponding figure for progression free survival is 59\% (Figure 2). Six out of 16 patients $(37.5 \%)$ showed complete radiological and functional response to salvage SBRS and were alive with no evidence of disease at the last visit. The median follow-up in these patients is 20 months (range 5-36 months). Six patients showed partial response and 2 had stable diseases. Only one patient developed local disease progression after SBRS. Three patients, one with progressive, one with stable disease, and one with partial response after SBRS died because of disease. All three patients who died of disease developed distant metastases and lungs were the site for distant metastases.

Four patients with partial response after salvage SBRS died from other causes. One patient was lost to follow up and 2 other patients were alive with evidence of disease. One out of two patients with evidence of disease showed partial response after SBRS. However she developed peritoneal dissemination and was given salvage chemotherapy. The other patient with stable local disease is in close follow up without any further treatment and showed no other signs of disease progression at 6 months. 
All patients were studied for quality of life using RTOG scoring system. ${ }^{11}$ Three patients (19\%) developed grade 4 late complications either vesicovaginal or rectovaginal fistulae or subileus attack. Another patient who had a history of diabetes mellitus and a diagnosis of arteriosclerosis in the iliac artery developed a thrombus in the right iliac artery. Three patients (19\%) developed G2-3 proctitis, and 1 patient experienced lymph edema in the lower extremity.

\section{DISCUSSION}

Clinical management of locoregional relapses from gynecologic malignancies after multiple previous treatments is challenging. Bulky recurrences can cause severe cancer related complications that worsen the quality of life. Salvage treatment options, including exenterative surgery and chemotherapy, produce very low cure rates with a cost of high complication rate. In one study by Fleisch et al, 203 patients with locally advanced or recurrent cancer were treated with pelvic exenteration and 5 year overall survival has been shown to be only $21.5 \%$ in total and $32 \%$ in patients with R0 resection. ${ }^{12}$ The complication rates for radical exenterative surgery can be as high as $75 \%$ for early and $83 \%$ for late complications. ${ }^{13-15}$ Systemic salvage chemotherapyis mainly considered palliative due to low response rates and negligible impact on long term survival. In a literature review by Pectasides et $\mathrm{a}^{16}$, the response rates to single agent chemotherapy ranged between $7-68 \%$ with the highest rates reported with cisplatinum. Both topotekan and paclitaxel in combination with cisplatin have yielded superior response rates and progression free survival rates without diminishing the quality of life. Though combination chemotherapy regimens produced higher response rates, the median survival after combination chemotherapy is still poor and less than 12 months in most trials.

SBRS is a novel treatment modality which allows high radiation dose delivery in a co or non-coplanar fashion with submilimeter precision utilizing a linear accelerator mounted on a robotic arm. The dose fractionations used in SBRS ranges from 6-34 Gy per fraction and the aim is to achieve more potent radiobiological dose which is presumed to produce improved outcome. The precisely distributed dose also gives the opportunity to spare the normal tissues in vicinity. In a dosimetric study performed by Cengiz et al. ${ }^{17}$, when compared to high dose rate brachytherapy, SBRS plans had better target coverage and better sparing of critical organs. SBRS is used mainly for small non metastatic primary cancer and oligometastases. Several phase II trials have shown encouraging results in early stage lung and primary hepatocelluler cancer in addition to lung and liver oligometastases. ${ }^{8,18-22}$ Similar excellent results in pain relief and local control have also been reported especially in patients who had been treated with spine SBRS. ${ }^{8,23}$ In recent years several prospective trials were conducted in prostate and renal cell carcinoma, well known as being radioresistant to conventional irradiation, and early results were mainly successive without any significant increase in complication rates..$^{24-26}$ SBRS has also been used as a salvage treatment modality for patients with recurrent head-and-neck cancer. ${ }^{27}$ Good local control was achieved with a relatively high rate of morbidity and related mortality in that study.

Tumor persistence or recurrence within the pelvis, not the metastatic disease, is the major cause of death in patients suffering from cervical cancer. A successful local treatment can produce high cure rates in these patients. However despite aggressive surgical approaches and new chemotherapy regimens patients with recurrent disease have very poor prognosis with one year survival rate between 15 and $20 \%{ }^{28}$ Theoretically SBRS has a great potential in the management of recurrent and locally advanced gynecologic cancer. The complete and total clinical response rates of SBRS in our patients with recurrent cancer are $37.5 \%$ and $75 \%$ with one-year progression free and overall survival rates of 59\% and $60.3 \%$ respectively which are higher than conventional salvage treatment options. Similar to our results, Guckenberger et al reported $81 \%$ local control at 3 years, $59 \%$ median survival at 2 years with SBRS in 19 patients with recurrent cervical or endometrial cancer. ${ }^{10}$ Deadoto et al on the other hand reported $66 \%$ of complete clinical response and $63.6 \% 2$ year overall survival with SBRS in patients with recurrent gynecologic cancer. ${ }^{9}$

The main concern of salvage SBRS is the potential severe late toxicity. Grade 4 late toxicities for genitourinary and gastrointestinal systems after SBRS 
in our patients is $19 \%$. In addition one patient developed a thrombus in the iliac artery and a surgical procedure had to be done. However she had predisposing medical conditions as having diabetes mellitus and previous history of atherosclerosis of the affected artery. Eleven patients in our series had been treated with external beam radiotherapy as initial treatment before recurrence and 4 patients who did not receive previous radiotherapy were given 45-50 Gy external radiotherapy before SBRS. Furthermore the majority of our patients received one to three major surgeries either as initial treatment or at the time of recurrence. Our late complication rates are comparable to Guckenberger et al. s' who reported 2 intestino-vaginal fistulae and 1 grade IV small bowel ileus in 19 patients treated with salvage SBRS. ${ }^{10}$

Successful local treatment of locally recurrent gynecological cancer may lead to high cure rates. SBRS in this regard is a promising treatment modality with high local control rates and reasonable complication rates.

\section{Acknowledgement}

This study is supported by Hacettepe University Research Grant 105 A 101009

\section{REFERENCES}

1. Landoni F, Maneo A, Colombo A, et al. Randomized study of radical surgery or radiotherapy for stage lb- Ila cervical cancer. Lancet 350: 535-540, 1997.

2. Rose PG, Bundy BN, Watkins EB, et al. Concurrent Cisplatin based radiotherapy and chemotherapy for locally advanced cervical cancer. N Engl J Med 340: $1144-1153,1999$.

3. Benedet JL, Odicino F, Maisnneuve P, et al. Carcinoma of the cervix Uteri. Int J Gynaecol Obstet 83 (Suppl 1): 41-78, 2003.

4. Bonomi P, Blessing JA, Stehman FB, et al. Randomized trial of three Cisplatin dose schedules in squamus carcinoma of the cervix: Gynecologic Group Study. J Clin Oncol 3: 1079-1085, 1985.

5. Brunschwig A. Complete excision of pelvic vissera for advanced carcinoma. A one-stage abdominoperineal operation with end colostomy and bilateral ureteral implantation into colon above the colostomy. Cancer 1: 177-183, 1948.

6. Friedlander M, Grogan M. Guidelines for the treatment of recurrent and metastatic cervical cancer. Oncologist 7: 342-347, 2002.
7. Wulf J, Haedinger U, Oppitz U, et al. Stereotactic boost irradiation for targets in abdomen or pelvis. Radiother Oncol 70: 31-36, 2004.

8. Timmerman RD, Kavanagh BD, Cho LC, et al. Stereotactic body radiotherapy in multiple organ sites. J Clin Oncol 25: 947-952, 2007.

9. Deadato F, Machia G, Grialdi L, et al. Stereotacic radiotherapy in recurrent gynecological cancer: A case studies. Oncology Reports 22: 415-419, 2009.

10. Guckenberger M, Bachmann J, Wulf J, et al. Stereotactic body radiotherapy for local boost irradiation in unfavourable locally recurrent gynaecological cancer. Radiother Oncol 94: 53-59, 2010.

11. Rubin P, Constine LS, Fajardo LF, et al. The RTOG Late Effects Working Group.Late effects on normal tissues (LENT)scoring system. Int J Radiat Oncol Biol Phys 31:1041-1091, 1995.

12. Fleisch MC, Pantke P, Beckmann MW, et al. Predictors for long term survival after interdisciplinay salvage surgery for advanced or recurrent gynecologic cancers. J Surg Oncol 95: 476-84, 2007.

13. Spahn M, Weiss $C$, Bader $P$, et al. The role of exenterative surgery and urinary diversin in persistent or locally recurrent gynecoloical malignancy: Complications and survival. Urol Int 85: 16-22, 2010.

14. Roos EJ, Van Eickeren MA, Boon TA, Heintz AP. Pelvic exenteration as treatment of recurrent or advanced gynecologic and urologic cancer. Int J Gynecol Cancer 5: 624-629, 2005.

15. Salom EM, Mendez LE, Schey D, et al. Continet İleocolic urinary reservoir (Miami pouch): The university of Miami experience over 15 years. Am J Obstet Gynecol 190: 994-1003, 2004.

16. Pectasides D, Kamposioras K, Papaxoinis G, Pctasides E. Chemotherapy for recurent cervical cancer. Cancer Treatment Reviews 34: 603-613, 2008.

17. Cengiz M, Dogan A, Ozyigit G, et al. Comparison of respective dose distribution patterns of intracavitary brachytherapy and stereotactic body radiotherapy for cervical cancer. Brachytherapy 11: 125-129, 2012.

18. Timmerman R, Paulus R, Galvin J, et al. Stereotactic body radition therapy for inoperable early stage lung cancer. JAMA 303: 1070-1076, 2010.

19. Choi BO, Choi IB, Jang HS, et al. Steotactic body radiation therapy with or without transarterial chemembolisation or patients with primary hepatocellular carcinoma: Preliminary analysis. BMC Cancer 8: 351, 2008.

20. Katz AW, Carey-Sampson M, Muhs AG, et al. Hypofractionated stereotactic body radiation therapy (SBRS) for limited hepatic metastases. Int Radiat Oncol Biol Phys 67: 793-798, 2007.

21. Fritz P, Kraus HJ, Muhlnickel W, et al. Stereotactic single dose irradiation of stage I non small cell lung cancer and lung metastases. Radiat Oncol 1: 30, 2006. 
22. Onishi H, Araki T, Shirato H, et al. Stereotactic hypofractionated high dose irradiation for stage I non small cell lung carcinoma: Clinical outcome in 245 subjects in a Japanese multiinstitutional study. Cancer 101: 1623-1631, 2004.

23. Nguyen QN, Shiu AS, Rhides LD, et al. Management of spinal metastases from renal cell carcinoma using stereotactic body radiotherapy. Int J Radiat Oncol Biol Phys 76: 1185-1192, 2010.

24. Tang Cl, Loblaw DA, Cheung P, et al. Phase I/II study of a five fraction hypofractionated accelerated radiotherapy treatment fo low risk localised prostate cancer: early results of pHART3. Clin Oncol (R Coll Radioll) 20: 729-737, 2008.

25. Wiegner EA, King CR. Sexual function after stereotactic body radiotherapy for prostate cancer: Results of a prospective cinical trial. Int J Radiat Oncol Biol Phys 78: 442-448, 2010.

26. Svedman C, Sandström P, Pisa P, et al. A prospective phase II trial of using extracranial stereotactic radiotherapy in primary and metastatc renal cell carcinoma. Acta Oncol 45: 870-875, 2006.

27. Cengiz M, Ozyiğit G, Yazici G, et al. Salvage Reirradiaton with Stereotactic Body Radiotherapy for Locally Recurrent Head-and-Neck Tumors. Int J Radiat Oncol Biol Phys 81: 104-109, 2011.

28. Bonomi P, Blessing JA, Stehman FB, DiSaia PJ, Walton L, Major FJ. Randomized trial of three cisplatin dose schedules in squamous cell carcinoma of the cervix: A Gynecologic Oncology Group Study. J Clin Oncol 3: 1079-1085, 1985.

\section{Correspondence}

Dr. Ferah YILDIZ

Hacettepe Üniversitesi Tıp Fakültesi

Radyasyon Onkolojisi Anabilim Dalı

06100, Sihhiye, ANKARA / TURKEY

Tel: (+90.312) 3053290

Fax: (+90.312) 3092914

e-mail: fyildiz@hacettepe.edu.tr 